\title{
HEQ
}

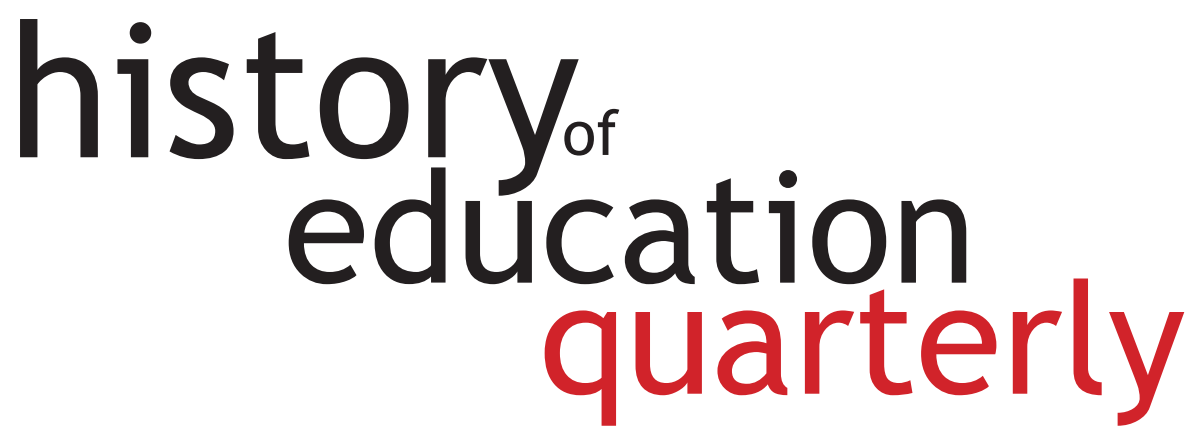

DEATH THE VACCINATOR.

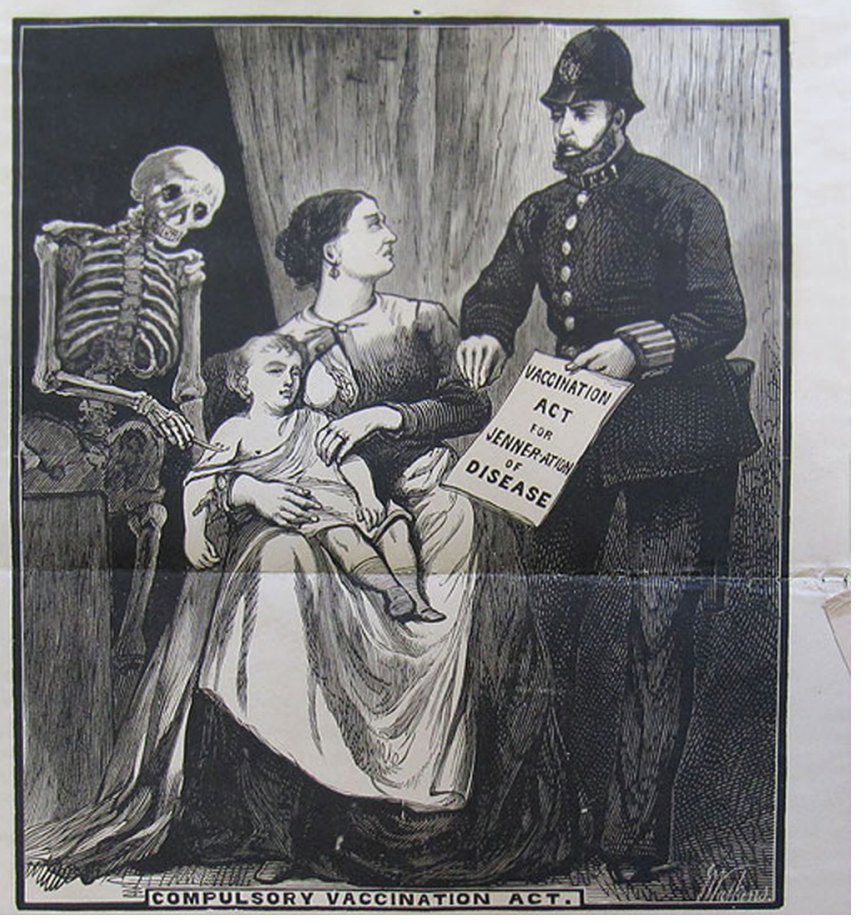


Article Submissions: Manuscripts must be submitted electronically to the History of Education Quarterly manuscript submission site at journals.sfu.ca/heq. Questions regarding submissions can be directed to the editorial staff at HEQedit@uw.edu. The editors will only consider articles that have been submitted exclusively to the History of Education Quarterly.

Book Reviews: Assignments of reviews are made from a file of potential reviewers. To have your name added to that file, please send your curriculum vitae to the book review editor at heqbooks@uw.edu. Requests to review particular books cannot be honored.

HISTORY OF EDUCATION QUARTERLY (Print ISSN: 0018-2680 Online ISSN: 1748-5959) is published quarterly on behalf of the History of Education Society in conjunction with The College of Education, University of Washington, Box 353600, Miller Hall, Seattle, WA 98195 by Cambridge University Press, One Liberty Plaza, New York, NY 10006.

Postmaster: Send all address changes to History of Education Quarterly, Cambridge University Press, Journals Fulfillment Dept., One Liberty Plaza, New York, NY 10006.

Publisher: History of Education Quarterly is published by Cambridge University Press, One Liberty Plaza, New York, NY 10006; Telephone: +1 212-337-5000; Email: newyork@cambridge.org

\section{Information for Subscribers}

History of Education Quarterly is published in 4 issues per year. Institutional subscription prices for 2019 are: Print \& Online: \$291; Print Only: \$268; Online Only: \$233. For customers in North America, email subscriptions_newyork@cambridge.org or call (800) 872-7423, option 4. For customers outside North America, email journals@cambridge.org or call +44 (0)1223 326070

Back Issues: Single issues from the current volume are available at the current single-issue price from subscriptions_newyork@cambridge.org. Earlier issues may be obtained from Periodicals Service Company, 351 Fairview Avenue - Ste 300, Hudson, NY 12534, USA. Telephone: +1 518 822-9300; Email: psc@periodicals.com

\section{Copyright and Copying}

Copyright (C) 2019 History of Education Society. All rights reserved. No part of this publication may be reproduced in any form or by any means, photocopying, electronic, or otherwise, without permission in writing from Cambridge University Press. Policies, request forms, and contacts are available at: http://www.cambridge.org/about-us/rights-permissions/

Permission to copy (for users in the USA) is available from the Copyright Clearance Center (CCC), http://www.copyright.com,info@copyright.com

Advertising: To advertise in the journal please email USAdSales@cambridge.org or call +1 212 337-5053 (for customers in North America); email ad_sales@cambridge.org or call +44 1223 325083 in the rest of the world.

\section{Disclaimer}

Statements of facts and opinion in the articles in History of Education Quarterly are those of the respective authors and contributors and not of the History of Education Society or Cambridge University Press. Neither Cambridge University Press nor the History of Education Society make any representation, express or implied, in respect of the accuracy of the material in this journal and cannot accept any legal responsibility or liability for any errors or omissions that may be made. 


\section{History \\ of Education \\ Quarterly}

Volume $59 \cdot$ Number $2 \cdot$ May 2019

\section{Contents}

HES Presidential Address

161 School Vaccination Wars: The Rise of Anti-Science in the American Anti-Vaccination Societies, 1879-1929

Kim Tolley

\section{Articles}

195 When Experimental Was Mainstream: The Rise and Fall of Experimental Colleges, 1957-1979

Reid Pitney Higginson

227 Clinical Technique, Tacit Resistance: Progressive Education Experimentation in the Jim Crow South William G. Wraga

257 How to Write a History Textbook: The Willard-

Willson Debate over History Education in the Common School Era

Peter B. Knupfer

\section{Book Reviews}

Crain, Reading Children: Literacy, Property, and the Dilemmas of Childhood in Nineteenth-Century America;

Ringel, Commercializing Childhood: Children's Magazines, Urban Gentility, and the Ideal of the Child Consumer in the United States, 1823-1918;

Speicher, Schooling Readers: Reading Common Schools in Nineteenth-Century American Fiction

Reviewed by Lorinda Cohoon 

Implementation of Brown v. Board of Education in Virginia Reviewed by Alexander Hyres

$294 \quad$ Fraser and Lefty, Teaching Teachers: Changing Paths and Enduring Debates

Reviewed by Jack Schneider

297 Gamble, Contesting French West Africa: Battles over Schools and the Colonial Order, 1900-1950

Reviewed by Rebecca Rogers

$300 \quad$ Ogren and VanOverbeke, eds., Rethinking Campus Life:

New Perspectives on the History of College Students in the

United States

Reviewed by Kate Rousmaniere

303 Rankin, A People's History of Computing in the United States Reviewed by Amy Sue Bix

$306 \quad$ Varel, The Lost Black Scholar: Resurrecting Allison Davis in American Social Thought

Reviewed by Jerry Gershenhorn

309 Williamson-Lott, Jim Crow Campus: Higher Education and the Struggle for a New Southern Social Order

Reviewed by Cally L. Waite

For complete information on the various History of Education Society awards and deadlines, please refer to the society's official website at http:// www.historyofeducation.org/.

PHOTO CREDIT: "Death the Vaccinator," late 1800s. The London Society for the Abolition of Compulsory Vaccination. Courtesy of the Historical Medical Library of The College of Physicians of Philadelphia. 